\title{
Intramedullary spinal cord metastasis of lung cancer presenting with acute urinary retention: a case report
}

\author{
Akciğer kanserinde akut üriner retansiyon ile farkedilen intramedullar spinal kord metastazı: olgu \\ sunumu
}

Cenk Ahmet SEN, Erkan SAHIN, Cagatay ARSLAN

\begin{abstract}
Intramedullary spinal cord metastasis is a rare entity. In this case report, we described an 82-year-old male patient with lung cancer who developed acute urinary retention during palliative radiotherapy for painful rib metastases. Left lower limb paresis occurred subsequently. Magnetic resonance imaging (MRI) scan revealed intramedullary spinal cord metastasis at the 11th-12th thoracic spine level. We decided to give steroid treatment and apply palliative radiotherapy. Spinal cord compression is generally seen due to vertebral metastases and compression fractures. Intramedullary spinal cord metastasis is a rare entity with only case reports in the literature. We aim to draw attention to this rare entity and increase awareness among physicians.
\end{abstract}

Keywords: Intramedullary spinal cord metastasis, Acute urinary retention, Lung cancer

Cenk Ahmet Sen (局)

Department of Radiation Oncology, School of Medicine, Izmir Universty, Izmir, Turkey

e-mail:cenkasen@gmail.com

Erkan Sahin

Department of Radiology, School of Medicine, Izmir Universty, Izmir, Turkey

Cagatay Arslan

Department of Medical Oncology, School of Medicine, Izmir Universty, Izmir, Turkey

Submitted/Gönderme: 15.05 .2016

Accepted/Kabul: 10.08.2016
ÖZ

İntramedullar spinal kord metastazı nadir görülen bir durumdur. Ağrılı kostal metastaza yönelik radyoterapi uygulanan 82 yaşındaki akciğer kanserli bir olguda akut üriner retansiyon ve ardından sol alt ekstremite parezisi gelişti. Manyetik rezonans görüntüleme (MRG)'de torakal 11-12 vertebral aralığında intramedullar spinal kord metastazı saptanan hastaya steroid tedavi ve radyoterapi uyguland1. Spinal kord basıları genellikle vertebra metastazları ve kompresyon fraktürlerine bağlı olarak gelişir. Intramedullar spinal kord metastazları ise nadirdir ve literatürde olgu sunumları şeklinde raporlanmıştır. Nadir görülen bu olguyu klinik değerlendirme amaciyla raporladik.

Anahtar kelimeler: İntramedullar spinal kord metastazı, Akut üriner retansiyon, Akciğer kanseri

\section{Introduction}

Intramedullary spinal cord metastasis (ISCM) is a rare entity seen in the course of malignant tumors. In autopsy series, the incidence is reported as $2 \%$ in patients with malignancies $[1,2]$. Due to the low incidence of treated cases, standard treatment methods are still to be defined. Early diagnosis of the ISCM and microsurgical operations can slightly improve the prognosis and neurological deficit, but surgical resection usually is not recommended for these patients [3]. Patients with ISCM are generally in poor performance status, and have visceral metastases. Thus, radiotherapy and steroid therapy are still the main treatment options. However, clinical benefits are limited [4]. The clinical course is rapidly progressive with permanent neurological morbidity, and poor survival [5]. 


\section{Case Report}

An 82-year-old male admitted to radiation oncology department due to severe pain of the right chest wall. He had a one-pack-a-day history of smoking for more than 50 years. His Eastern Cooperative Oncology Group (ECOG) Scale Performance Status was 2. The source of the pain was a $3-\mathrm{cm}$ metastatic lesion located between the $3 \mathrm{rd}$, and the 4 th ribs seen in the chest computed tomography. There was a $5 \mathrm{~cm}$ mass in the right upper lung. We planned stereotactic radiosurgery to the painful intercostal lesion. His pain reduced on the 2nd day of treatment. A sudden urinary retention and abdominal pain occurred. Physical examination and abdominal ultrasonography showed urinary retention with greatly enlarged bladder. Thoracic spine magnetic resonance imaging (MRI) demonstrated an intramedullary spinal cord lesion at the 11th-12th thoracic spine level (Figure 1). Craniocaudal dimension of the lesion was about $2 \mathrm{~cm}$. Brain MRI was normal. Subsequently numbness and disability occurred at his left lower extremity. Neurological examination showed monoparesis of the left lower extremity $(2 / 5)$. We treated the patient with immediate corticosteroid treatment and radiotherapy. Total radiotherapy dose was 30 Gy given in 10 fractions with a daily fraction dose of $3 \mathrm{~Gy}$. Urinary catheter was removed on the 15th day after radiotherapy. Urinary retention did not occur again, but there was no regression in his left lower extremity paralysis. The patient died due to his cancer after 3 months from the diagnosis.

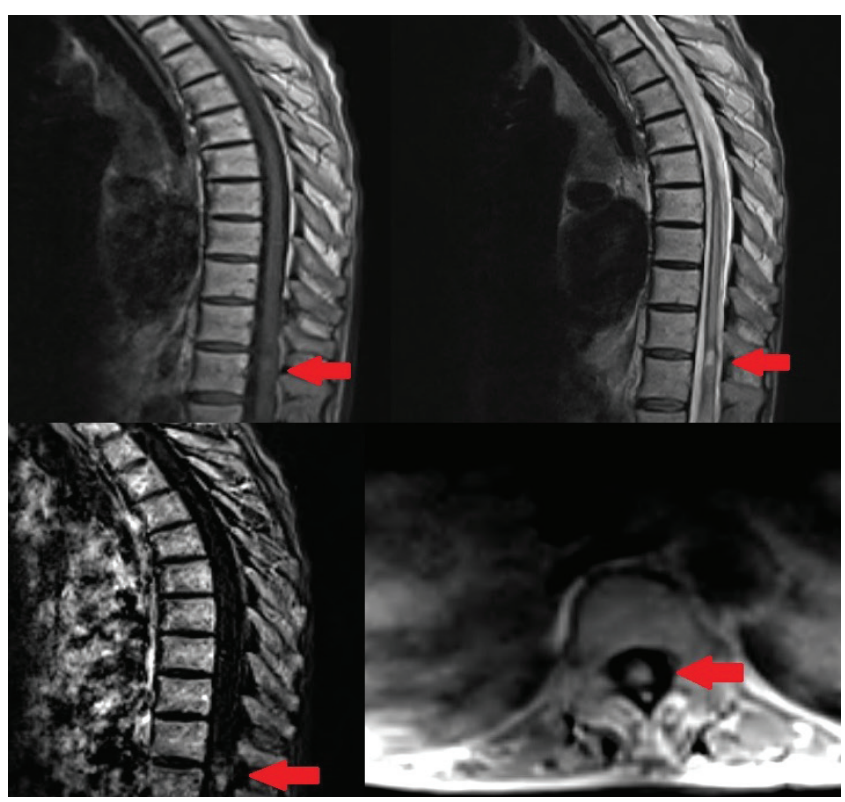

Figure 1. Sagittal T1 and T2-w, post contrast sagittal and axial thoracic spine MRI images demonstrated a contrast enhanced intramedullary spinal cord lesion with a diameter of $20 \times 7 \mathrm{~mm}$, at the 11th-12th thoracic spine level.

\section{Discussion}

ISCM is a rare entity, accounting for only $0.1 \%-0.4 \%$ of all cancer patients [6]. However, the incidence is on the rise due to the improved survival of cancer patients [7]. Most of the patients with ISCM have brain and systemic metastases at the time of diagnosis [8]. Spreading route to intramedullary spinal region might occur in 3 ways; hematogenous spread, direct invasion by meningeal tumors and direct invasion from contiguous structures. Overall survival is very poor. Symptoms may change from minor to major neurological symptoms. Our patient had monoparesis of the left lower extremity $(2 / 5)$. Mortality rate is $80 \%$ during the first three to four months following the occurrence of the first symptom. Death occurs due to complications of neurological damage and progressive cancer. Our patient died due to his cancer after 3 months from the diagnosis.

Willis was the first to review the pathological evaluation of the subject [9]. In major clinical series dating back to the 1972's, 9 patients were reported [10]. The largest clinical series with 40 patients were reported in 1996 [11]. In the PubMed search, a total of 248 patients with ISCM were identified (Table I).

Table I. The cases identified in the PubMed search

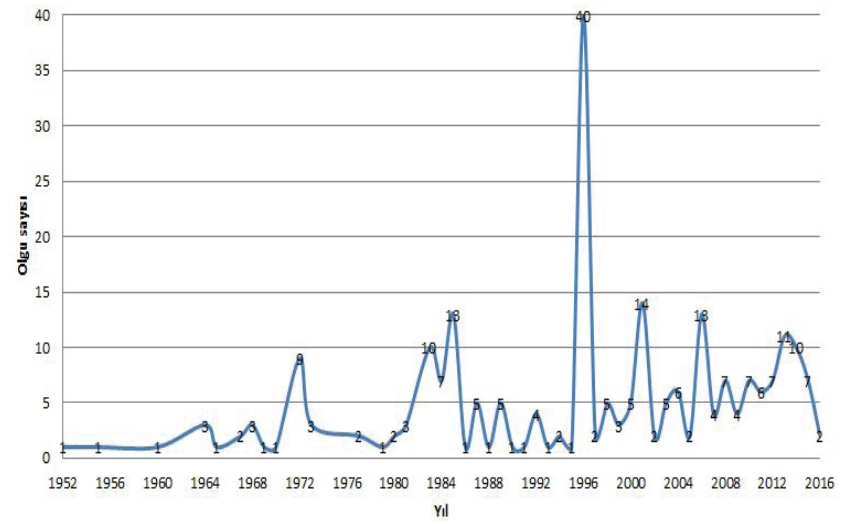

Gadolinium-enhanced MRI shows high sensitivity and has become the gold standard in diagnosis of all spinal canal lesions [12]. PET-CT has a sensitivity of $96 \%$ in detecting spinal metastasis [13].

Radiotherapy is the standard treatment option. Intensity modulated radiation therapy, cyberknife and tomotherapy are modern radiotherapy techniques, but no significant data support their routine use. In selected cases, microsurgical techniques might be effective. Microsurgical removal of ISCM can improve the quality of life in early diagnosis in selected patients. Aggressive surgical treatment with 
postoperative adjuvant radiotherapy and chemotherapy might prolong survival.

Possibility of intramedullary metastasis should be considered in case of acute urinary retention in the lack of vertebral metastasis.

\section{References}

1. Chason JL, Walker FB, Landers JM. Metastatic carcinoma in the central nervous system and dorsal root ganglia. Cancer 1963;16:781-7. doi: 10.1002/1097-0142(196306)16:6<781.

2. Costigan DA, Winkelman MD. Intramedullary spinal cord metastasis. A clinicopathological study of 13 cases. J Neurosurg 1985;62:227-33.

3. Sung WS, Sung MJ, Chan JH, et al. Intramedullary spinal cord metastases: a 20-year institutional experience with a comprehensive literature review. World Neurosurg 2013;79:576-84. doi: 10.1016/j.wneu.2012.04.005

4. Hashii H, Mizumoto M, Kanemoto A, et al. Radiotherapy for patients with symptomatic intramedullary spinal cord metastasis. J Radiat Res 2011;52:641-5. doi: 10.1269/ jrr.10187.

5. Kalayci M, Cagavi F, Gul S, et al. Intramedullary spinal cord metastases: diagnosis and treatment and illustrated review. Acta Neurochir (Wien) 2004;146:1347-54. doi: 10.1007/ s00701-004-0386-1.
6. Lee SS, Kim MK, Sym SJ, et al. Intramedullary Spinal Cord Metastases: A Single-Institution Experience. J Neurooncol 2007;84:85-9. doi: 10.1007/s11060-007-9345-z.

7. Payer S, Mende KC, Westphal M, et al. Intramedullary spinal cord metastases: an increasingly common diagnosis. Neurosurg Focus 2015;39:E15. doi: 10.3171/2015.5.FOCUS15149.

8. Grasso G, Meli F, Patti R, et al. Intramedullary spinal cord tumor presenting as the initial manifestation of metastatic colon cancer: case report and review of the literature. Spinal Cord 2007;45:793-96. doi: 1362-4393/07

9. Willis RA. The spread of tumors in the human body. London: J\&A Churchill, 1934.

10. Edelson RN, Deck MD, Posner JB. Intramedullary spinal cord metastases. Clinical and radiographic findings in nine cases. Neurology 1972;22:1222-31. doi:10.1212/WNL.22.12.1222

11. Schiff D, O'Neill BP. Intramedullary spinal cord metastases: clinical features and treatment outcome. Neurology 1996;47:906-12. doi:10.1212/WNL.47.4.906

12. Loughrey GJ, Collins CD, Todd SM, et al. Magnetic resonance imaging in the management of suspected spinal canal disease in patients with known malignancy. Clin Radiol 2000;55:849-55. doi: 10.1053/crad.2000.0547

13. Kaya RA, Dalkilic T, Ozer F, et al. Intramedullary spinal cord metastasis: a rare and devastating complication of cancertwo case reports. Neurologia Medico Chirurgica (Tokyo) 2003;43:612-5. doi: 10.2176/nmc.43.612 